\title{
Impact of the Proposed Energy Tax on Nuclear Electric Generating Technologies
}

\author{
Office of Nuclear Energy \\ United States Department of Energy
}

By

Thomas A. Edmunds

Alan D. Lamont

Alan D. Pasternak

William F. Rousseau

Carl E. Walter

May 1993

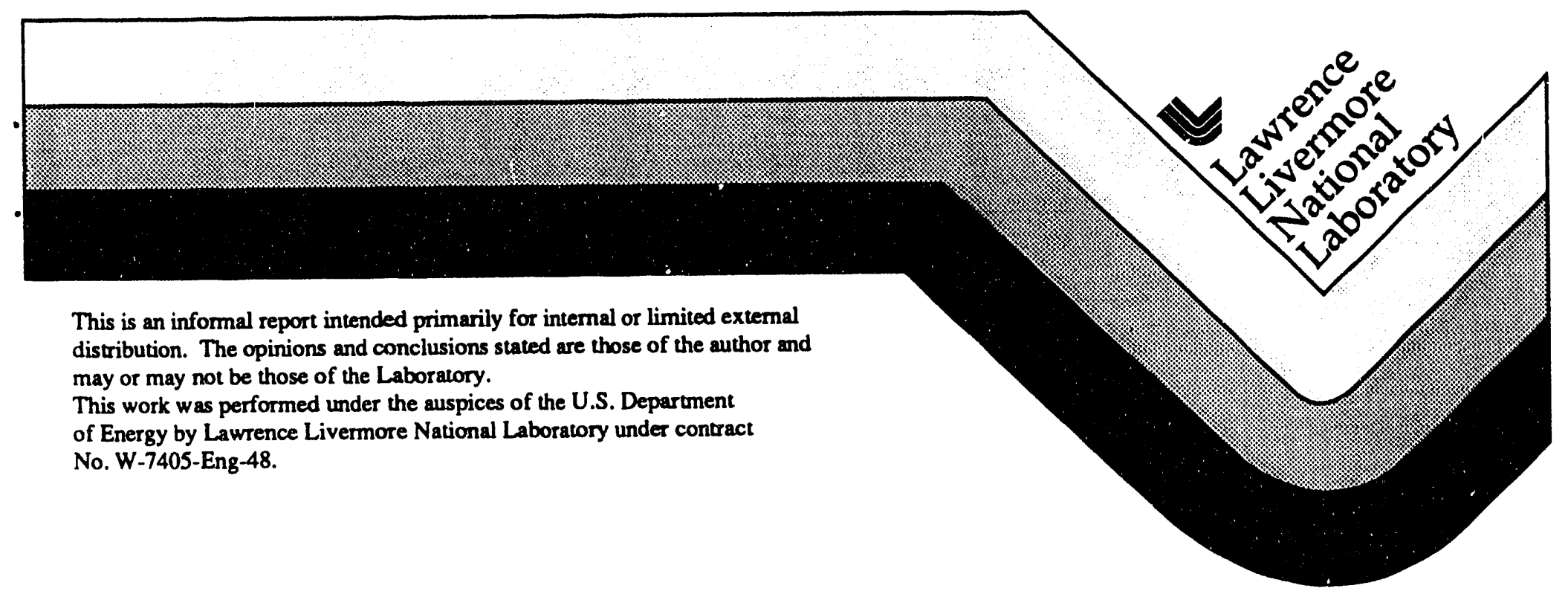




\section{DISCLAIMER}

This documeat was prepared as an acoount of work sponsored by an ageacy of the United States Government. Veither the United States Governmeat nor the University of Califoraia nor any of their employees, makes any warmanty, expres or implied, or aswmes any legal liability or rexponsibility for the accuracy, completeneas. or usefulness of any information, apparatus, product, or process disclosed, or represents that its use would not infringe privately owned rights. Reference herain to any specific conmercial products, proces, or service by trade anme, trademark, imanufacturer, or otherwise, does not necesarily constitute or imply its endorsement. recommendation, or favoriag by the United States Goverament or the University of California. The views and opinioas of authors expraved herein do not necesarily state or reflect those of the United States Government or the University of Caltfornia, and shall not be used for advertising or product endorsesneat purposes.

This repert has been reproduced directly from the best available copy.

Available to DOE and DOE contractors from the Once of Scientific and Technieal Information P.O. Box 62, Oak Rldge, TN 3731

Prices available from (615) 576-8401, FIS 626-8401

Available to the public from the

National Technieal Information Service

US. Department of Commerce 5285 Port Rojal Rd. Springfield, VA 22161 


\section{Table of Contents}

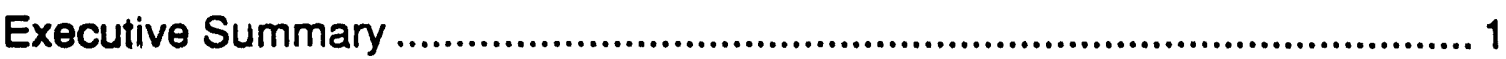

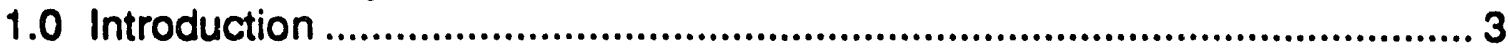

2.0 Treasury Department Proposal for Energy Tax ........................................... 3

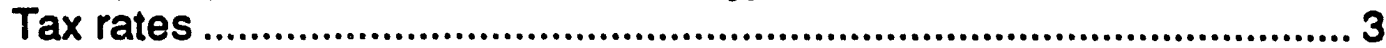

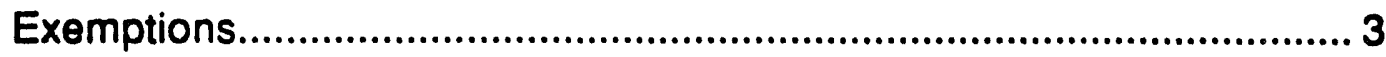

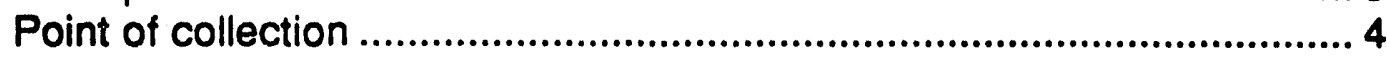

Discussion ....................................................................................... 4

3.0 Comparison of impacts on fossil and nuclear generating technologies ...... 4

Generation cost impact ....................................................................... 4

Environmental and other externality considerations.................................. 6

4.0 Comparison of tax options for nuclear energy ........................................... 7

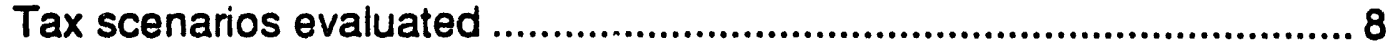

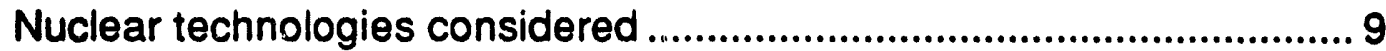

Results of the evaluation for technologies............................................ 9

5.0 Summary of findings ................................................................................... 12

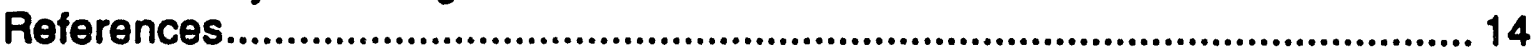

Appendix A - Description of Model for Evaluating Tax Impact .......................... 15

Overview of the model............................................................................... 15

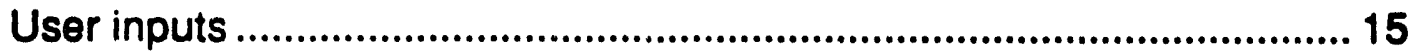

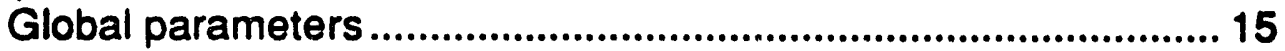

Technology-specific parameters................................................ 16

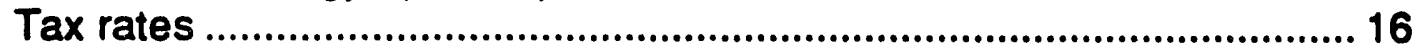

Calculation of busbar cost impact for implementation options ................. 16

Appendix B - Description of Reactor Technologies......................................... 20

Appendix C - Cost Impact on Nuclear and Fossil Generating Technologies .... 21

Appendix D - Treasury Statement.....................................................................22 


\section{Executive Summary}

The President's proposed energy tax will impact the economics of conventional and advanced nuclear plant designs, as well as competing baseload generation technologies. This report compares the impacts of the proposed tax on nuclear generation with the impacts on other electrical energy generation technologies, and examines the implications of other methods for implementing the tax. The tax as proposed affects coal-fired and nuclear generation about equally, but different implementation methods can substantially change the impact of the tax on nuclear generation.

The proposed tax on nuclear energy $(\$ 2.66 / \mathrm{MWh}$ net electrical generation) has essentially the same impact as the proposed tax on coal-fired generation ( $\$ 0.257 / \mathrm{mmBtu}$ in coal). Although the impact for coal-fired energy is approximately $\$ 0.10 / \mathrm{MWh}$ lower than that for nuclear energy generated with conventional LWR technology, this cost differential represents $0.2 \%$ of the total cost of generation, and is smaller than station-to-station and regional variations in production costs.

Alternative methods for implementing the tax can substantially alter the impact on nuclear generation costs. In addition, there is substantial variation in the impact of an energy tax on different nuclear generating technologies. Thermal efficiency, fuel enrichment, and fuel residence times play major roles in determining the impact of the tax.

The impact of the energy tax is higher if the tax rate is applied to gross electrical energy rather than to net electrical energy produced. This is because energy used by station auxiliaries would be taxed. Applying the tax to net electrical generation is analogous to exempting from tax the oil that refineries consume in operations.

Interest charges can also increase the impact of the tax on nuclear energy if the tax is collected from producers early in the nuclear fuel cycle, who are later reimbursed by consumers at the time of generation. For example, the tax impact is $\$ 2.92 / \mathrm{MWh}$ if the tax is levied at fuel loading, and $\$ 2.11 / \mathrm{MWh}$ if the tax ir levied at fuel discharge. The effect is even more acute (\$5.23/MWh) when uranium is taxed at the mine mouth and consumed four or five years later.

Furthermore, if $235 \mathrm{U}$ is taxed prior to enrichment, then tax is paid on $235 \mathrm{U}$ in tails material that is discarded. For a conventional LWR, tails losses increase the tax impact by over $40 \%$.

Other implementation methods can lower the tax impact on nuclear-generated energy. If the tax were based on the energy content of $235 \mathrm{U}$ rather than heat generation in the reactor, the impact for low-enriched uranium fuels would be smaller. This is because plutonium breeding and subsequent plutonium fission energy would not be taxed. For example, the tax for a conventional light water reactor is $\$ 2.92 / \mathrm{MWh}$ if it is based upon the energy content in $235 \mathrm{U}$, and $\$ 3.19 / \mathrm{MWh}$ if it is based upon thermal energy generated in 
the reactor. However, if the tax is based upon the energy in both $235 \mathrm{U}$ and $238 \mathrm{U}$ (based upon plutonium breeding), the tax impact increases by a factor of over 100 , to $\$ 650 / \mathrm{MWh}$ for a conventional LWR.

We also note that consideration of externalities may suggest lower taxes on nuclear-generated energy. For example, if one of the objectives of the energy tax is to reduce emissions, then an argument can be made that the tax on nuclear energy should be lower than the tax on coal-generated energy by an amount that reflects the environmental damage associated with coal-fired generation. Under the Clean Air Act Amendments of 1990, existing coal-fired plants are granted allowances to emit sulfur, and thus do not fully pay for environmental damages caused by their emissions. The current market value of these emission rights granted to existing coal-fired plants is roughly equivalent to the proposed energy tax. The relative tax rates for coal and nuclear generation could be adjusted to reflect this eternality, thus suggesting that existing nuclear plants should not be taxed.

In conclusion, the proposed energy tax on nuclear-generated electricity appears to have about the same impact as the proposed tax on chemical energy in coal, and thus would not substantially affect the relative economics ci these two base-load generation technologies. However, alternative implementation methods could increase or decrease the impact of the tax on nuclear generation costs. 


\subsection{Introduction}

The President's new economic initiatives include an energy tax that will affect the costs of power from most electric generating technologies. The tax on nuclear power could be applied in a number of different ways at several different points in the fuel cycle. These different approaches could have different effects on the generation costs and benefits of advanced reactors. The Office of Nuclear Energy has developed models for assessing the costs and benefits of advanced reactor cycles which must be updated to take into account the impacts of the proposed tax. This report has been prepared to assess the spectrum of impacts of the energy tax on nuclear power and can be used in updating the Office's economic models.

This study was conducted in the following steps. First, the most authoritative statement of the proposed tax available at this time was obtained. Then the impacts of the proposed tax on the costs of nuclear and fossil fueled generation were compared. Finally several other possible approaches to taxing nuclear energy were evaluated. The cost impact on several advanced nuclear technologies and a current light water technology were computed. Finally, the rationale for the energy tax as applied to various electric generating muthods was examined. The sections below describe these steps in detail.

\subsection{Treasury Department Proposal for Energy Tax}

The Treasury Department has proposed a set of taxes to be imposed on fossil fuels, electricity generated from nuclear and hydro generators, and imporied electricity. The entire tax proposal as of April 1993 is reproduced in Apnendix D. This section highlights the provisions relevant to electrical generation.

\section{Tax rates}

The tax as proposed would tax fossil fuels on the basis of their energy content. The tax on fossil fuels is $\$ 0.257$ per million Btu, or $\$ 0.244$ per billion joules ( $\$ 0.244 / G J)$. However, a supplemental tax of $\$ 0.342$ per million Btu $(\$ 0.324 / \mathrm{GJ}$ ) will be imposed on refined petroleum products (for a total tax of $\$ 0.599$ per million Btu or $\$ 0.568 /$ GJ on refined petroleum products). For nuclear and hydro-generated electricity, a tax will be imposed directly on the electrical energy generated. The Treasury Department proposes that a tax of $\$ 2.66 / \mathrm{MWh}$ be imposed on nuclear and hydro-generated electricity.

\section{Exemptions}

Several exemptions are proposed. Those relevant to the electrical generating industry include exported fuels and eiectricity; hydro-electric energy from pumped storage; solar, wind, and geothermal energy; biomass; and imported electricity, if the importer can establish that the electricity was not generated from fossil fuels, hydropower, or nuclear power. 


\section{Point of collection}

The proposal specifies the point at which tax on each fuel will be collected, and which party will be responsible for paying it. Those taxes relevant to this study are described here. Petroleum products will be taxed at the refinery tailgate, to be paid by the refiner. Natural gas will be taxed at the city gate, to be collected and paid by the pipeline (but the distribution company is the party that is actuaily liable for it). Coal will be taxed at the point of receipt by the end-user, to be paid by the end-user. Nuclear- and hydro-jenerated electricity will be taxed at the utility, to be paid by the utility. Electrical power generated by independent power producers will be taxed at the utility that receives the electricity, to be paid by the utility. The independent power producer will receive a credit for taxes paid on fossil fuel used to generate the electricity. Taxes on other generation technologies are delineated in Appendix C.

\section{Discussion}

In the case of nuclear generated electricity, the Treasury Department states that: "The Btu content used to determine the tax on nuclear generated electricity and hydroelectricity would be the national average of Btus required to produce fossil-fuel-generated electricity." The proposed tax of \$2.66/Mwh is consistent with $=\pi i$ energy tax of $\$ 0.244 / \mathrm{GJ}$ on a net heat rate of $10.9 \mathrm{GJ} / \mathrm{MWh}$ $(10,350 \mathrm{Btu} / \mathrm{kWh})$ for "ossil-fuel generated electricity. The Treasury Department does not explain why an average actual heat rate for nuclear plants is not used instead.

\subsection{Comparison of impacts on fossil and nuclear generating technologies}

\section{Generation cost impact}

The tax can influence the decisions that an electric utility makes by affecting operating costs and total life cycle costs. The impact on operating costs will influence the utility's decisions about dispatch of existing stations, while the life cycle cost impact influences decisions about investments in one technology versus another. This section compares the operating and life cycle cost impacts of the tax for two nuclear technologies, two baseload coal technologies, and two peaking technologies.

These calculations used the cost data presented in the Electric Power Research Institute's Technology Assessment Guide (TAG) (EPRI, 1989), which provides data for each component of the cost of installing and operating electric generators and the tax rate proposed by the Treasury Department on net electrical output. TAG is a reference for making estimates as a first step in the selection of technologies for new electric generating capacity. As such, the values given in TAG are general and apply to broad regions of the country. The calculations made in Section 4 and Appendix $A$ use slightly different values that are specific to the technologies considered. 
The calculations described here estimate the levelized busbar price that would have to be charged per unit of electrical energy over the life of a new facility in order to fully recover its capital and operating costs. They do not take into account income tax or rate design considerations because treatments vary from state to state. Of course, taxes and rate design measures that do not discriminate among technologies would tend produce the same tax impact on all technologies.

The calculations are summarized iri Table 1 below. The complete calculations and input data are shown in Appendix C, Table C-1. As shown by the data, the tax on the nuclear base load technologies is approximately $\$ 0.10$ per MWh, or $4 \%$, higher than the tax on the coal-fired technologies. This difference in tax represents $4 \%$ of the operating cost of a coal-fired plant, and would probably be smaller than station-to-station variations in heat rate and regional variations in fuel costs. This is consistent with our discussions with electric utility executives who stated that they did not expect the tax to affect their dispatching of coal and nuclear stations.

Table 1 Impact of energy tax on generating technologies

\begin{tabular}{|c|c|c|c|c|c|c|c|c|c|}
\hline $\begin{array}{l}\text { Technology } \\
\text { and EPFI Case* }\end{array}$ & Fuel & $\begin{array}{l}\text { Duty } \\
\text { Cycle }\end{array}$ & $\begin{array}{l}\text { Tax, } \\
\text { S/MWh }\end{array}$ & $\begin{array}{l}\text { Oper. } \\
\text { Costs, } \\
\text { S/MWh } \\
\text { W/o tax }\end{array}$ & $\begin{array}{c}\text { Total } \\
\text { Life } \\
\text { Cycle } \\
\text { Costs, } \\
\text { swWh } \\
\text { W/o } \\
\text { tax }\end{array}$ & $\begin{array}{l}\text { Opar. } \\
\text { Costs, } \\
\text { SNMWh } \\
\text { whth tax }\end{array}$ & $\begin{array}{l}\text { Total } \\
\text { Llte } \\
\text { Cycle } \\
\text { Costs, } \\
\text { SWWh } \\
\text { whth } \\
\text { tax }\end{array}$ & $\begin{array}{l}\text { Tax as } \\
\% \text { of } \\
\text { Opor. } \\
\text { Costs }\end{array}$ & $\begin{array}{c}\text { Tax as } \\
\% \text { of } \\
\text { Total } \\
\text { Costs }\end{array}$ \\
\hline $\begin{array}{l}\text { Pulverized coal } \\
\text { (TAG 1.1) }\end{array}$ & coal & base & 2.58 & 24.0 & 51.9 & 26.6 & 54.5 & 10.0 & 5.0 \\
\hline $\begin{array}{l}\text { Atmospheric fluid } \\
\text { bed (TAG 9.1) }\end{array}$ & coal & base & 2.56 & 26.3 & 58.4 & 28.9 & 61.0 & 8.9 & 4.5 \\
\hline $\begin{array}{l}\text { Adv. light water } \\
\text { (TAG 60.1) }\end{array}$ & $\bar{U}$ & base & 2.66 & 19.3 & 47.7 & 22.0 & 50.4 & 12.0 & 5.3 \\
\hline $\begin{array}{l}\text { Combust. turbine } \\
\text { distil. (TAG 40.1) }\end{array}$ & oil & peak & 8.40 & 60.9 & 109.2 & 69.3 & 117.6 & 12.1 & 7.7 \\
\hline $\begin{array}{l}\text { Combust. turbine } \\
\text { gas (TAG 41.1) }\end{array}$ & $\begin{array}{l}\text { nat. } \\
\text { gas }\end{array}$ & peak & 3.87 & 48.3 & 103.4 & 52.2 & 107.3 & 7.4 & 3.6 \\
\hline
\end{tabular}

- Cases are taken from the Electric Power Research Institute's Technology Assessment Guide (TAG) (EPRI 1989)

The impact on total life cycle cost is even smaller, and affects the technologies almost uniformly. The difference in tax on coal and nuclear generation, $\$ 0.10$ per MWh, represents $0.2 \%$ of the life cycle cost of generation. 
For all of the baseload technologies, the tax ranges from 4.3 to $5.3 \%$ of the life cycle costs.

The tax affects peaking technologies most severely, increasing operating costs to $\$ 60.9$ and $\$ 48.3$ per $M W h$ on the distillate combustion turbine and the natural gas combustion turbine, respectively. Where cost effective, the tax could tend to encourage greater use of the intermediate and baseload generating technologies because these technologies have better efficiencies.

\section{Environmental and other externality considerations}

A variety of environmental, regulatory, and national security considerations could also play a role in determining energy tax rates for different generating technologies. These considerations include $\mathrm{SO}_{x}$ and $\mathrm{CO}_{2}$ emissions, regulatory costs, waste disposal costs, and costs of dependence upon foreign energy resources. One could argue that the tax on generating technologies that subsidize the costs of these externalities should be lower than the tax on those technologies that do not. For example, the fact that nuclear plants pay a tax for waste disposal while coal plants do not might be used to justify a lower tax on nuclear energy. Similarly, under the Omnibus Budget Reconciliation Act of 1990, nuclear plant operations are required to fully fund the costs of the Nuclear Regulatory Commission while there is no similar mandate for fossil fuel-fueled facilities to cover the cost of their regulations. Note that the proposed tax on oil is much higher than the proposed rate for other energy sources, perhaps reflecting an energy security externality. $\mathrm{SO}_{2}$ emissions by coal-fired facilities is an externality that can be quantified, as discussed below.

Under normal plant operating conditions, the environmental impact of coal-fired generation is more severe than that for nuclear generation. Furthermore, existing coal-fired generating plants are granted the right to emit a base level of pollutants. An estimate of the cost of the uncompensated environmental damage can be derived using the provisions of the Clean Air Act Amendments of 1990 (CAA).

Under the CAA, coal-fired units in commercial operation before 1985 will be granted the right to emit $2.5 \mathrm{lb} \mathrm{SO} 2$ per million $\mathrm{Btu}(1.1 \mathrm{~kg} \mathrm{SO} / \mathrm{GJ})$ until the year 2000 , and $1.2 \mathrm{lb} \mathrm{SO}_{2}$ per million Btu $\left(0.52 \mathrm{~kg} \mathrm{SO}_{2} / \mathrm{GJ}\right)$ thereafter. Assuming a net heat rate of $10.9 \mathrm{GJ} / \mathrm{MWh}$ for a coal-fired generating station, the corresponding allowable emission rates would be $12 \mathrm{~kg} \mathrm{SO}_{2} / \mathrm{MWh}$ prior to the year 2000 and $5.7 \mathrm{~kg} \mathrm{SO} / \mathrm{MWh}$ thereafter.

Successful bids for emission allowances offered by the Environmental Protection Administration under the spot market provisions of the CAA have recently ranged from $\$ 131$ to $\$ 450$ per ton of $\mathrm{SO}_{2}(\$ 0.14 \text { to } \$ 0.50 \text { per } \mathrm{kg} \mathrm{SO})_{2}$ '. These prices reflect costs of reducing emissions below what is allowed. If the allowance quota has been set correctly, the environmental impact cost of

1 The New York Times, pg. 19, March 30,1993 
emissions should be about equal to the cost of emission reduction. Thus, these emission permit prices imply an environmental impact cost ranging from $\$ 1.7 / \mathrm{MWh}$ to $\$ 6.0 / \mathrm{MWh}$ prior to the year 2000 , and from $\$ 0.80 / \mathrm{MWh}$ to $\$ 2.9 / \mathrm{MWh}$ thereafter. Note that the value of emissions rights granted to existing coal-fired generating stations is in the same range as the proposed energy tax (\$2.66/MWh).

\subsection{Comparison of tax options for nuclear energy}

This section compares the impact of several different options for taxing nuclear energy. These options consider several different tax bases and the application of the tax at different points in the fuel cycle. In the case of taxes applied at the reactor, the analysis considers taxes on net electric generation (this is the current Administration proposal), on gross electric generation, and heat released in the reactor. Next the analysis considers taxes levied on fuel mass at the time of fuel load or at the time of fuel discharge. Finally, the analysis evaluates a tax on uranium at the mine mouth.

The impacts of each of the tax scenarios on the busbar costs of electricity are evaluated for seven nuclear technologies. These cover a range of conventional nuclear and advanced designs, including the ALMR that uses taxfree plutonium derived from reprocessed fuel.

This comparison is made in terms of the impact that the taxes will have on the economic attractiveness of nuclear-generated electricity compared with electricity generated by other means. This is best expressed in terms of the increase in busbar electrical energy cost that will result from a tax, because this determines the economic attractiveness of a technology. Comparisons between taxes have also been made that focus on the equivalent sales taxes of various fuels. However, the apparent sales tax on fuel does not proportionately impact the total cost of generating electricity. The magnitude of the apparent fuel sales tax, therefore, will not strongly influence the electric utilities to invest in a particular generating technology.

In orde to assess the impact of various energy tax implementation scenarios, a spreadsheet model was developed to compute the increase in the cost of generation thatiwould arise from an energy tax. The model accepts three basic types of inputs. First, global industry parameters such as discount rate and the time required for various steps in the nuclear fuel cycle are specified. Second, nuclear reactor design parameters such as thermal efficiency, burnup, and fuel residence time in the core are input. Third, tax rates levied for each of seven tax implementation scenarios are specified. Values for these parameters have been derived from a range of sources and have been included in the model. The user has the option of overriding these inputs to study the impact of new reactor technologies or tax implementation scenarios. 


\section{Tax scenarios evaluated}

The model uses these inputs to compute the increase in cost at the busbar, measured in $\$ / M W h$ of net electrical energy generation. This tax impact is computed for each of seven tax implementation scenarios. The seven scenarios evaluated, the tax rates, and the tax bases are as follows:

1) Tax net electricity generation ( $\$ 2.66 / \mathrm{MWh}-n e t)$ - This is the plan proposed by the Treasury Department. The tax is applied to each net MWh of electrical energy generated, at the time of generation. This implies that energy used in station auxiliaries is not taxed, and that there is very little delay between the time the utility pays the tax and the time the tax is collected from consumers. The tax rate is equivalent to a tax of $\$ 0.244 / \mathrm{GJ}$ on heat energy in conjunction with a net plant heat rate of $10.9 \mathrm{GJ} / \mathrm{MWh}$.

2) Tax gross electricity generation (\$2.66 /MWh-gross) - Tax is applied to each gross MWh of electrical energy generated at the time of generation. This implies that energy used in station auxiliaries is taxed.

3) Tax heat generated in reactor $(\$ 0.244 / G J)$ - Tax is applied to heat generated in a reactor at a rate equivalent to that applied to energy in coal and natural gas.

4) Tax fuel from reactor at discharge $(\$ 17,000 / \mathrm{kg} 235 \mathrm{U})$ - Tax is based upon the mass of $235 \mathrm{U}$ in the fuel at fuel load, and is paid by the utility when the spent fuel is taken out of the reactor core. The tax rate is computed by multiplying the amount of energy contained in the $235 \mathrm{U}$ by the basic energy tax rate of $\$ 0.244 / G J$. The energy content calculations are described in Appendix A. Multiplying the energy content by the energy tax rate yields an effective mass tax rate of $\$ 17,000 / \mathrm{kg} 235 \mathrm{U}$.

5) Tax fuel to reactor at fuel load $(\$ 17,000 / \mathrm{kg} 235 \mathrm{U})$ - The tax basis is the same as that used in scenario 4 , but the tax is applied to nuclear fuel when it is placed in the reactor core.

6) Tax uranium at the mine mouth $(\$ 17,000 / \mathrm{kg} 235 \mathrm{U})$ - The tax basis is the same as that used in scenarios 4 and 5 , but the tax is applied to uranium at the mine mouth.

7) Tax max $U$ energy at mine mouth $(\$ 15,000 / \mathrm{kg} U)$ - Tax is applied to uranium at the mine mouth. The tax rate is derived by computing the maximum amount of energy that could be recovered from both $235 \mathrm{U}$ and $238 \mathrm{U}$ atoms, assuming that all $238 \mathrm{U}$ atoms are converted to $239 \mathrm{Pu}$ and absorb neutrons. Under this assumption, the energy tax of $\$ 0.244 / \mathrm{GJ}$ is applied to the energy content of uranium at $61,500 \mathrm{GJ} / \mathrm{kg}$ to yield $\$ 15,000 / \mathrm{kg} \mathrm{U}$. This scenario is unrealistic without fuel reprocessing.

Details of the economic impact computations are included in Appendix A. 


\section{Nuclear technologies considered}

The busbar imp:ict associated with each of these tax implementation scenarios is computed for each of the reactor technologies listed below:

\section{Acronym Reactor type}

Generic LWR Composite representation of commercial light water reactors

GE-ABWR General Electric Corp., advanced boiling water reactor

GE-SBWR General Electric Corp., simplified boiling water reactor

W-AP600 Westinghouse Electric Corp., active/passive pressurized water reactor

ABB Sys 80 Aesa Brown Boveri, System 80+

GA-MHTGR General Atomic Corp., modular high temperature gascooled reactor

GE-ALMR General Electric Corp., advanced liquid metal reactor

Pertinent reactor performance parameters are included in Appendix B.

\section{Results of the evaluation for technologies}

The results of these calculations are shown in Table 2 and Figure 1 below. The computations performed in the model and input parameters are described in more detail in Appendices A and B. 
Table 2 Impact of energy tax on nuclear generation technologies

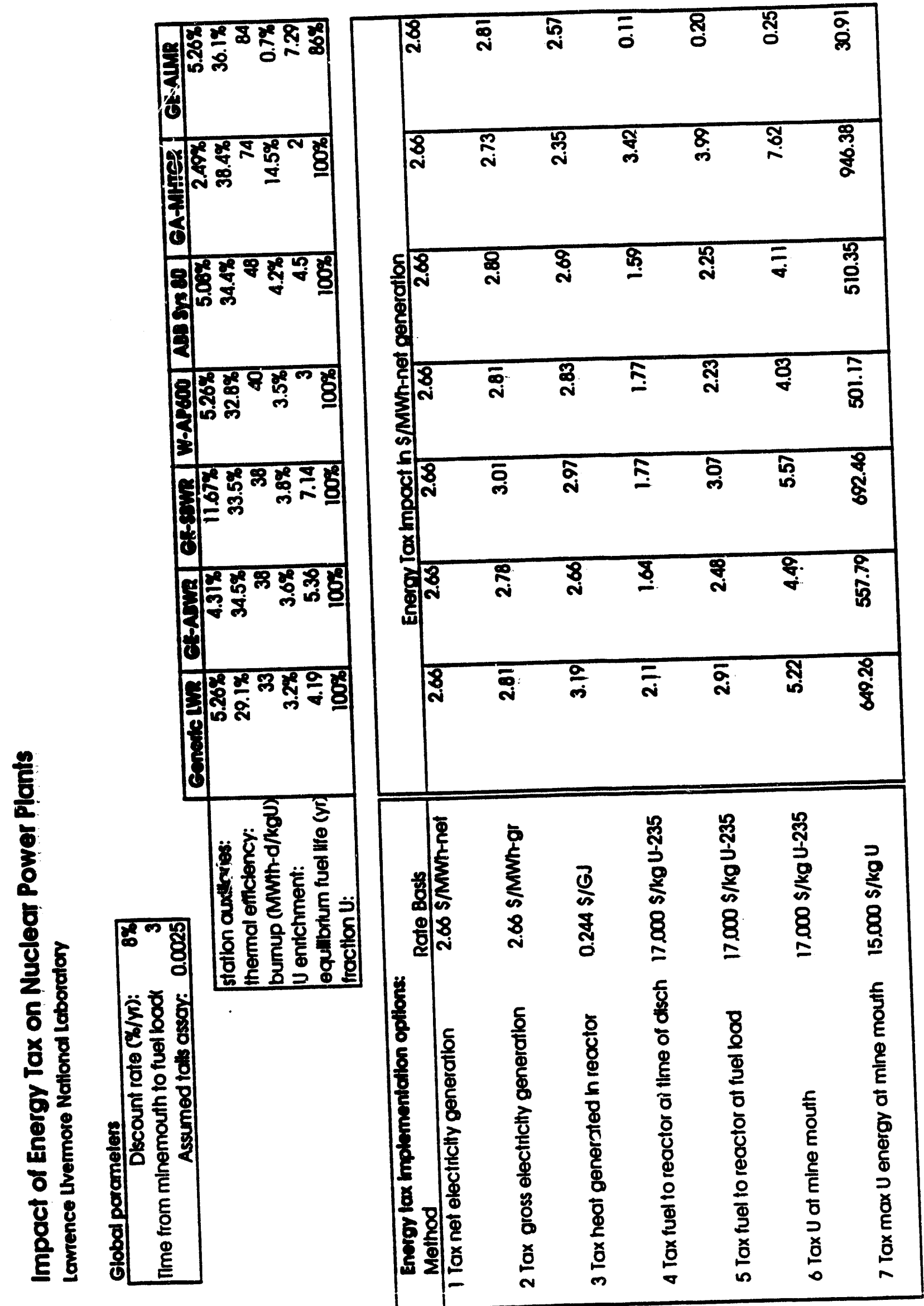


Figure 1 Busbar impact of energy tax options

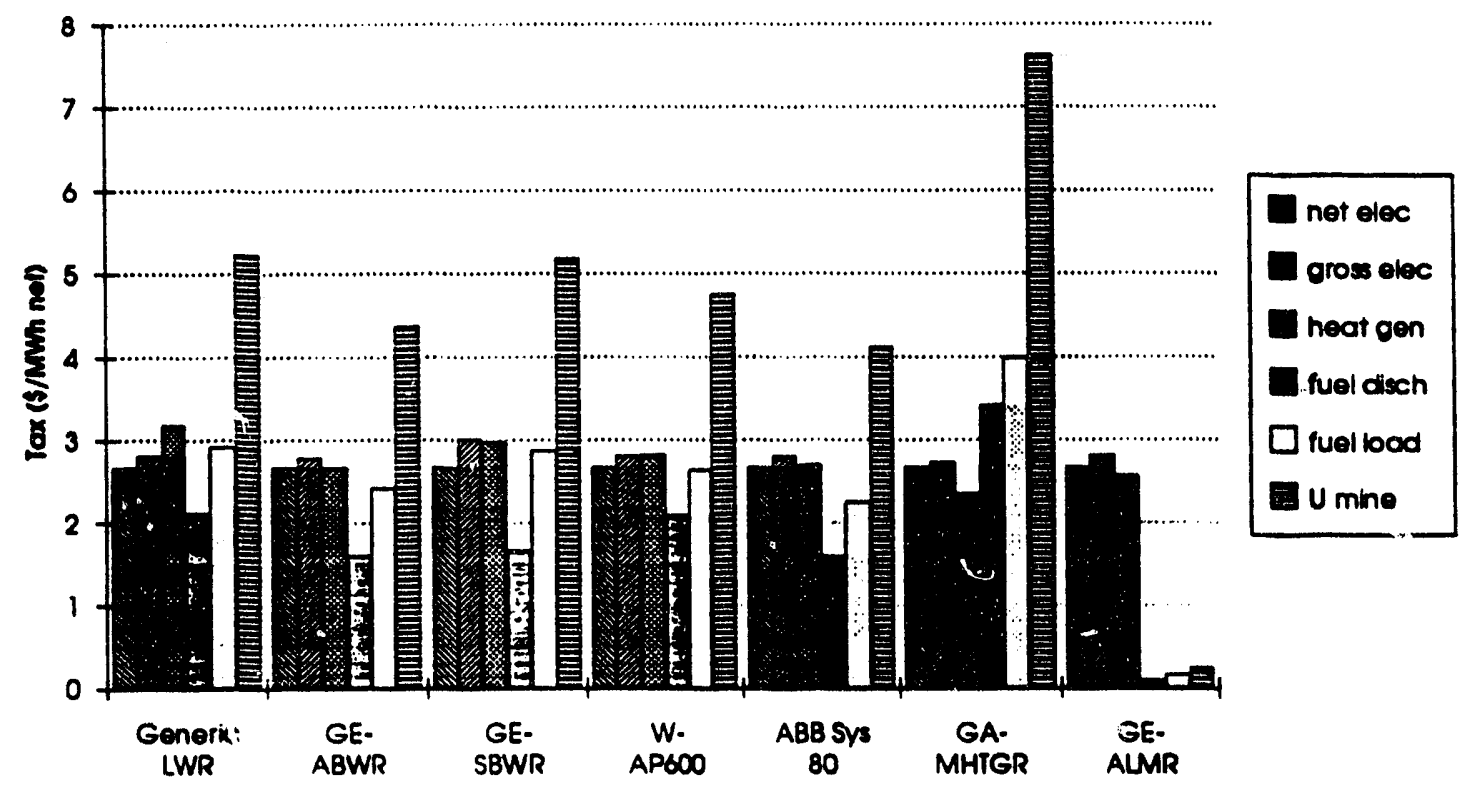

As indicated by the data in Table 2 and Figure 1, the first three tax implementation scenarios have about the same impact on busbar costs for all technologies. This is due to the fact that they all are based upon taxing heat released in the reactor.

A second general observation is that the tax impact is slightly higher when implemented at fuel load, and significantly higher when implemented at the mine mouth. This is partly due to financing charges associated with early payment $0 i^{\circ}$ the tax by utilities. In addition, in the case of taxes levied at the mine mouth, some taxed uranium is discarded by enrichment plants in the tails material. The effect is particularly striking for the GA-MHTGR, which uses fuel at $14.5 \%$ enrichment.

Specific comments regarding each of the tax implementation scenarios are as follows.

1) Tax net electricity generation (\$2.66 /MWh-net): Each reactor technology will pay the same tax of $\$ 2.66 / \mathrm{MWh}-\mathrm{n}$.

2) Tax gross electricity generation (\$2.66 /MWh-gross): The impact on busbar cost ranges from a low of $\$ 2.73 / \mathrm{MWh}-n$ for the GA-MHTGR reactor to a high of $\$ 3.01 / \mathrm{MWh}-n$ for the GE-SBWR reactor. The magnitude of the impact scales with the station auxiliaries.

3) Tax heat generated in reactor $(\$ 0.244 / G \mathrm{~J})$ : The impact ranges from a low of $\$ 2.35 / \mathrm{MWh}-n$ for the GA-MHTGR to a high of $\$ 3.19 / \mathrm{MWh}-\mathrm{n}$ for the generic 
light water reactor. The thermal efficiency and station auxiliaries determine the magnitude of the impact.

4) Tax fuel irom reactor at discharge $(\$ 17,000 / \mathrm{kg} 235 \mathrm{U})$ : The impact ranges from a low of $\$ 0.03 / \mathrm{MWh}-n$ for the GE-ALMR to a high of $\$ 3.42 / \mathrm{MWh}-n$ for the GA-MHTGR. Because the tax would be collected by the utility from customers when the energy is generated and paid at a later date when the fuel is discharged, there is an interest subsidy to the utility provided by its customers. The low tax for the GE-ALMR can be attributed to the long fuel life (7.29 years) in conjunction with the low enrichment at equilibrium $(0.17 \%)$. The long fuel life produces a significant interest subsidy, which reduces the impast of the tax by $31 \%$.

5) Tax fuel to reactor at fuel load $(\$ 17,000 / \mathrm{kg} 235 \mathrm{U})$ : The impact ranges from a low of $\$ 0.05 / \mathrm{MWh}-n$ for the GE-ALMR to a high of $\$ 3.99 / \mathrm{MWh}-n$ for the GA-MHTGR. Because the tax is paid first by the utility and collected from customers at a later date when the energy is generated, there is an interest subsidy to the rate payers provided by the utility.

6) Tax uranium at the mine mouth $(\$ 17,000 / \mathrm{kg} 235 \mathrm{U})$ : The impact ranges from a low of $\$ 0.25 / \mathrm{MWh}-n$ for the GE-ALMR to a high of $\$ 10.19 / \mathrm{MWh}-n$ for the GA-MHTGR. The impact of the tax is increased by the loss of uranium in the enrichment plant tails and the significant delay between the time the tax is paid to the government by the fuel supplier and the time the tax is collected from the consumer. The impact of the tax is highly dependent upon the enrichment of the fuel used by the design.

7) Tax max $U$ energy at mine mouth $(\$ 15,000 / \mathrm{kg} U)$ : The impact ranges from a low of \$31/MWh for the GE-ALMR to a high of \$947/MWh for the GA-MHTGR. Note that the impact is over 100 times larger than that observed in scenario 6 . This can be attributed to the fact that $100 \%$ of the atoms in the uranium are being taxed in this scenario, as opposed to roughly $1 \%$ of the atoms as in scenario 6 .

\subsection{Summary of findings}

The taxes proposed by the Treasury Department appear to affect the production costs of nuclear power and its competitors to about the same degree. The differences in impact may be smaller than station-to-station or regional variations in costs.

Alternative methods for taxing energy generated in reactors produce similar impacts on the busbar cost of electricity. Larger tax impacts are observed if taxes are applied at earlier points in the nuclear fuel cycle. This increase is due to two effects. First, interest charges accrue if taxes are levied on fuel producers earlier in the fuel cycle and collected from consumers later, at the time of generation. Second, if energy in $235 \mathrm{U}$ is taxed at the uranium mine mouth, taxed $235 \mathrm{U}$ atoms are later discarded as tails in the enrichment process. This increases the effective tax on those $235 \mathrm{U}$ atoms that are in the enriched 
fuel. The impact is higher for nuclear technologies that require highly enriched fuel (e.g. General Atomic's Modular High Temperature Gas-Cooled Reactor). Reactors that use low-enriched fuel and significant plutonium breeding (e.g. General Electric's Advanced Liquid Metal Reactor) have a significantly lower tax impact if only the energy in $235 U$ is taxed. 


\section{References}

Electric Power Research Institute (EPRI-TAG), Technology Assessment Guide, EPRI P-6587-L, Vol. 1:Rev. 6; September 1989

Omnibus Budget Reconciliation Act of 1990, Public Law 101-508

Clean Air Act Amendments of 1990 (CAA), Public Law 101-549, Title IV Acid Deposition Control

Lamarsh, John R., Introduction to Nuclear Reactor Theory, Addison-Wesley, Reading, MA, pp. 90, 104, 556 (1972)

Villani, S., Uranium Enrichment, Springer-Verlag, New York, pg. 154 (1979). 


\section{Appendix A - Description of Model for Evaluating Tax Impact}

\section{Overview of the model}

As discussed in Section 4, a model to estimate the impact of alternative approaches to levying an energy tax has been developed. For comparison purposes, the model romputes the impact of various implementation schemes on the busbar cost of electrical energy from various nuclear power plant designs. The model accepts input parameters that describe the general economic environment, and a set of design parameters for each nuclear reactor technology. The user also specifies the tax rate and basis, $\theta .9 . \$ 17,000 / \mathrm{kg} 235 \mathrm{U}$ at fuel load. Given this information, the model computes the increase in energy cost at the busbar that can be attributed to the energy tax. The model has been implemented on an electronic spreadsheet package (Microsoft Excel), and is displayed in Table 2. The user inputs and the calculations for the Generic Light Water Reactor (LWR) are described below. Calculations for the other reactor technologies are similar to the Generic LWR computations.

\section{User inputs}

The basis for determining the user inputs are described below. Values representative of the current nuclear industry configuration have been used where possible. Design parameters for advanced nuclear technologies are discussed in Appendix B.

\section{Global parameters}

Global parameters that are specified by the user are shown in the upper left-hand corner of Table 2. The first parameter is a discount rate, which is used to estimate the cost impact due to potential time delays between the time the energy tax is paid and when it is collected from the consumer. A reasonable proxy for this parameter is a utility's after-tax-weighted average cost of capital.

The second global parameter is the time delay from the uranium mine mouth to fuel loading. This parameter is used to estimate the impact of having the Treasury Department collect the tax at the mine mouth, and having the utility collect the tax from the consumer at some point after the fuel is loaded into the reactor.

The third global parameter is the optimal tails assay for uranium enrichment plants. This value will vary in accordance with the relative prices of enrichment plant feedstock and electric power for the plant. Because the energy tax could increase both the cost of electric power and the cost of feedstock, the net impact of the tax could be either an increase or a decrease in optimal tails assay.

We examined the impact of increased power cost to an enrichment plant. For example, to produce uranium at an enrichment of $3.2 \% 235 \mathrm{U}$ at a nominal tails assay of 0.0025 , the impact of a $\$ 0.244 / \mathrm{GJ}$ tax levied on a $10.9 \mathrm{GJ} / \mathrm{MWh}$ 
coal plant that supplies power to an enrichment plant can be computed as follows:

$(\$ 0.244 / \mathrm{GJ})(10.9 \mathrm{GJ} / \mathrm{MWh})(2.05 \mathrm{MWh} / \mathrm{kg}$ SWU)(4.2 kg SWU/kg U product)

$=\$ 23 / \mathrm{kg} \mathrm{U}$ at $3.2 \%$ enrichment

$=\$ 720 / \mathrm{kg} 235 \mathrm{U}$

where the energy consumption per SWU is taken from Villani (1979). The increase in diffusion plant energy cost that can be attributed to the energy tax is a few percent of the total cost of nuclear fuel. The impact of tax on the uranium feedstock is much larger, and is described in the following sections.

\section{Technology-specific parameters}

Technology-specific parameters for seven reactor technologies have been developed and included in the model. The five parameters corresponding to a generic LWR are shown at the top of Table 2. Parameters for other reactor technologies are described in Appendix B. Each technology is represented by these same five parameters.

The first technology parameter, labeled "station aux," refers to the fraction of gross electrical generation that is used internally by the plant. Thermal efficiency is the second input, and is used to convert heat generation into gross electrical output. The third input, burnup, is expressed in megawatt days of thermal energy per $\mathrm{kg}$ of uranium. The fourth input parameter is the fuel life in years at equilibrium. It is obtained by dividing the core inventory by the refueling mass and multiplying by the fuel cycle time. The last parameter, fraction $U$, represents the fraction of fissile atoms in fresh fuel that are 235U. These technology parameters are used to estimate the impact of the energy tax or the busbar cost of electrical energy.

\section{Táx rates}

Seven tax implementation scenarios and tax rates corresponding to each are shown on the left side of Table 2. The user inputs the tax rate corresponding to the particular tax basis associated with the scenario. For example, in scenario

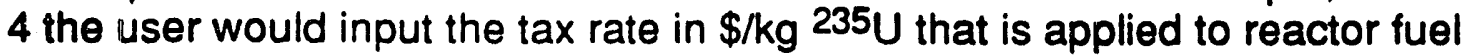
during a refueling outage.

\section{Calculation of busbar cost impact for implementation options}

The cells to the right of each implementation scenario contain estimates of the impact of the tax on the cost of a MWh of net generation for each of the reactor technologies. The computations for each implementation scenario are described below. 
Scenario 1: Tax net electricity generation

If the energy tax is applied directly to net electrical energy generated when it is generated, the busbar impact is simply the numerical value of the tax. This relationship is reflected in Table 2, where the tax is $\$ 2.66 / \mathrm{MWh}$-net.

Scenario 2: Tax gross electricity generation

If the energy tax is applied to gross electrical generation, the effective tax on net electrical energy (MWh-n) will be larger than the tax applied to gross electrical energy (MWh-g) by the factor 1/(1-station aux). The calculation in the example show in Table 2 would be performed as follows:

$(\$ 2.66 / \mathrm{MWh}-\mathrm{g})^{\star}(1 /(1-0.0526) \mathrm{MWh}-\mathrm{g} / \mathrm{MWh}-\mathrm{n})=\$ 2.81 / \mathrm{MWh}-\mathrm{n}$

Scenario 3: Tax heat generated in reactor

The energy tax could be applied to heat generated in the reactor at the rate of $\$ 0.244 / G J$. If the tax is applied on this basis, the impact on net electrical energy generation would be computed using the reactor thermal efficiency and the station auxiliaries. The calculation for the example show in Table 2 would proceed as follows:

(\$0.244/GJ)(3.6 GJ/MWh-th)/(0.291 MWh-g/MWh-th)

$$
(1 /(1-0.0526) \mathrm{MWh}-\mathrm{g} / \mathrm{Mwh}-\mathrm{n})=\$ 3.19 / \mathrm{MWh}-\mathrm{n}
$$

\section{Scenario 4: Tax fuel from reactor at fuel discharge}

The tax rate shown in scenario 4 is based upon taxing the energy content of $235 \mathrm{U}$ at a rate of $\$ 0.244 / \mathrm{GJ}$. Assuming an energy release of $200 \mathrm{MeV}$ per fission, and a fission to absorption cross section ratio of (577/678), the energy content of $235 \mathrm{U}$ is obtained as follows:

$$
\begin{aligned}
& \left(200 \frac{\mathrm{MeV}}{\text { fission }}\right)\left(\frac{577}{678} \frac{\text { tissions }}{{ }^{235} \mathrm{U}-\text { atom }}\right)\left(1.60 \times 10^{-2} \frac{\mathrm{GJ}}{\mathrm{MeV}}\right)\left(\frac{6.022 \times 10^{26} \text { atoms }-{ }^{235} \mathrm{U}}{235 \mathrm{~kg}-{ }^{235} \mathrm{U}}\right) \\
& =69,800 \frac{\mathrm{GJ}}{\mathrm{kg}-{ }^{235} \mathrm{U}}
\end{aligned}
$$

where, parameter values have been taken from Lamarsh (1972). Thus, multiplying the energy content by the energy tax rate yields an effective mass tax rate of $\$ 17,000 / \mathrm{kg} 235 \mathrm{U}$.

If the fuel in the reactor is taxed at fuel discharge and the revenue is collected during fuel burnup, then the utility would be collecting revenue during burnup and paying the tax several years later at fuel discharge. The interest subsidy effect of collecting revenue early and paying the tax later would reduce the impact of the tax. At a discount rate of $8 \%$ per year and a fuel life of 4.19 years, the interest subsidy would reduce the busbar impact of the tax by 
approximately $20 \%$, to $\$ 2.00 / \mathrm{MWh}-\mathrm{n}$. The value that appears in Table A.1, $\$ 2.11 / M W h-n$, is based upon an exact calculation that more accurately accounts for the cash fiuw stream. The exact formula is shown below.

$$
\operatorname{tax}(\$ / M W h-n)=\frac{r p T e^{-r T}}{f\left(1-e^{-t T}\right)}
$$

where: $r=$ discount rate for continuous compounding $(r=0.077$ to yield an $8 \%$ annual interest rate)

$p=\operatorname{tax}$ in $\$ / \mathrm{kg} U$

$T=$ equilibrium fuel life in years

$f=$ net electrical energy yield (MWh-n/kg U)

\section{Scenario 5: Tax fuel to reactor at fuel load}

If the tax of $\$ 17,000 / \mathrm{kg} 235 \mathrm{U}$ is applied at fuel load and the cost passed through to consumers during fuel burnup, then the utility would be paying the tax first and collecting the revenue several years later. Interest charges associated with tax prepayment would increase the busbar impact of the tax by approximately $20 \%$ for the parameters shown in Table 2, from $\$ 2.50 / \mathrm{MWh}-n$ to $\$ 2.92 / \mathrm{MWh}-\mathrm{n}$. The exact calculation is based upon the equation shown below.

$$
\operatorname{tax}(\$ / M W h-n)=\frac{r p T}{f\left(1-e^{-T T}\right)}
$$

Scenario 6: Tax uranium at mine mouth

The tax rate of $\$ 17,000 / \mathrm{kg} 235 \mathrm{U}$ could be levied on uranium at the mine mouth, prior to enrichment and fuel fabrication. Note that in the enrichment process, some of the taxed $235 \mathrm{U}$ atoms are discarded in the tails. This impact is described below.

The tax rate on naturally enriched uranium can be converted to a tax rate on enriched uranium using basic process equations related to uranium enrichment. In particular, the mass of feed required per unit mass of product can be computed using the following equation.

$$
\frac{m_{1}}{m_{p}}=\frac{e_{p}-e_{1}}{e_{1}-e_{t}}
$$

The parameters $m_{f}$ and $m_{p}$ refer to the mass of feed and product, respectively, and the parameters $e_{f}, e_{p}$, and $e_{t}$ refer to the enrichments of feed, product, and tails uranium, respectively. For the parameter values shown in Table 2 for the LWR, the ratio of feed to product is 6.41 . This implies that approximately $30 \%$ of the $235 \mathrm{U}$ in the feed is discarded in the tails, and that the tax impact is increased by over $40 \%$. 
The interest effect is substantial when the tax is applied at the mine mouth due to the additional delay between the time the tax is paid by the utility and when the revenue for energy generation is collected by the utility. Table 2 indicates that this delay is 3 years. Given a fuel life of 4 years, this would result in an average delay of approximately 5 years, and an increase in cost of approximately $60 \%$. The exact equation for computing the cost is shown below.

$$
\operatorname{tax}(\$ / M W h-n)=\frac{r p T e^{r T c}}{f\left(1-e^{-r T}\right)}
$$

where TC is the delay in the fuel cycle from mine mouth to fuel load.

Scenario 7: Tax max $U$ energy at mine mouth

The tax rate shown in scenario 7 is based upon taxing the energy content of both $235 \mathrm{U}$ and $238 \mathrm{U}$ (after conversion to $239 \mathrm{Pu}$ ) at a rate of $\$ 0.244 / \mathrm{GJ}$. The energy content of $235 \mathrm{U}$ was computed using the formula show in scenario 4. The energy content of 239pu is computed in a similar manner below.

$$
\begin{aligned}
& \left(208 \frac{\mathrm{MeV}}{\text { fission }}\right)\left(\frac{741}{1015} \frac{\text { fissions }}{{ }^{299} \mathrm{Pu}-\text { atom }}\right)\left(1.60 \times 10^{-22} \frac{\mathrm{GJ}}{\mathrm{MeV}}\right)\left(\frac{6.022 \times 10^{26} \text { atoms }-{ }^{29} \mathrm{Pu}}{239 \mathrm{~kg}-{ }^{239} \mathrm{Pu}}\right) \\
& =61,200 \frac{\mathrm{GJ}}{\mathrm{kg}-{ }^{299} \mathrm{Pu}}
\end{aligned}
$$

where, parameter values have been taken from Lamarsh (1972). The energy content in natural uranium is approximately equal to a weighted average of the energy in these two isotopes: $0.0071^{*} 69,800+(1-.0071)^{*} 61,200=61,300$ GJ per $\mathrm{kg}$ of natural uranium. Thus, multiplying the energy content by the energy tax rate yields an effective mass tax rate of $\$ 15,000 / \mathrm{kg} U$. 


\section{Appendix B - Description of Reactor Technologies}

Reactor technology parameters used in Table 2 are taken from the data shown below.

\section{Table B.1 Reactor technology parameters}

\begin{tabular}{|c|c|c|c|c|c|c|c|}
\hline & 1 & 2 & 3 & 4 & 5 & 6 & 7 \\
\hline & $\begin{array}{r}\text { Generic } \\
\text { LWR }\end{array}$ & $\begin{array}{r}G E \\
A B W R\end{array}$ & $\begin{array}{r}\text { GE } \\
\text { SBWR }\end{array}$ & $\begin{array}{r}W \\
\text { AP600 }\end{array}$ & $\begin{array}{r}\text { ABB } \\
\text { Syst80 }\end{array}$ & $\begin{array}{r}\text { GA } \\
\text { MHTGR }\end{array}$ & $\begin{array}{r}\text { GE } \\
\text { ALMR }\end{array}$ \\
\hline Invent, Mg & 134.0 & 155.0 & 94.0 & 66.9 & 104.9 & 3.6 & 22.6 \\
\hline Cycle,mo & 12 & 18 & 24 & 18 & 18 & 12 & 23 \\
\hline CapFact\% & 80 & 87.0 & 87.0 & 80 & 79 & 80 & 85 \\
\hline Reload,Mg & 32.0 & 49.2 & 33.4 & 21.4 & 35.0 & 1.8 & 5.9 \\
\hline Therm,MW & 3616 & 3926 & 2000 & 1940 & 3914 & 450 & 840 \\
\hline GrElec,MW & 1053 & 1356 & 670 & 664 & 1345 & 177 & 319 \\
\hline NotEl,MW & 1000 & 1300 & 600 & 600 & 1280 & 173 & 303 \\
\hline ElecAux,\% & 5.26 & 4.31 & 11.67 & 10.67 & 5.08 & 2.49 & 5.26 \\
\hline Not Ht Rt & 3.62 & 3.02 & 3.33 & 3.23 & 3.06 & 2.60 & 2.77 \\
\hline GrossEtf\% & 29.1 & 34.5 & 33.5 & 34.2 & 34.4 & 39.4 & 38.0 \\
\hline NotE $\% \%$ & 27.7 & 33.1 & 30.0 & 30.9 & 32.7 & 38.4 & 36.1 \\
\hline FuelRes,y & 4.19 & 4.72 & 5.63 & 4.69 & 4.50 & 2.00 & 7.29 \\
\hline BU,MWd/kg & 33 & 38 & 38 & 40 & 48 & 74 & 84 \\
\hline $\begin{array}{l}\text { Compln\%: } \\
\text { U-234 }\end{array}$ & 100 & 100 & 100 & 100 & 100 & 100 & 100 \\
\hline $\begin{array}{l}U-235 f \\
U-236\end{array}$ & 3.20 & 3.60 & 3.75 & 3.50 & 4.20 & 14.45 & 0.17 \\
\hline $\begin{array}{l}\text { U-238 } \\
\text { Pu-238 }\end{array}$ & 96.80 & 96.40 & 96.25 & 96.50 & 95.80 & 85.55 & $\begin{array}{r}87.61 \\
0.10\end{array}$ \\
\hline $\begin{array}{l}\text { Pu-239f } \\
\text { Pu-240 }\end{array}$ & & & & & & & $\begin{array}{l}8.97 \\
2.53\end{array}$ \\
\hline Pu-241f & & & & & & & 0.19 \\
\hline PU-242 & & & & & & & 0.10 \\
\hline MinorAct & & & & & & & 0.31 \\
\hline CompOut\%: & 100.00 & 100.00 & 100.01 & 100.01 & 100.01 & 100.00 & 100.01 \\
\hline$U-234$ & 0.02 & 0.02 & 0.02 & 0.02 & & & \\
\hline$U-235 f$ & 0.92 & 0.77 & 0.84 & 0.78 & 0.82 & 3.56 & 0.09 \\
\hline U-236 & 0.39 & 0.48 & 0.50 & 0.47 & 0.57 & 2.12 & 0.02 \\
\hline U-238 & 97.72 & 97.47 & 97.40 & 97.45 & 97.32 & 92.20 & 85.76 \\
\hline Pu-238 & 0.01 & 0.03 & 0.03 & 0.03 & 0.02 & 0.05 & 0.12 \\
\hline Pu-239f & 0.53 & 0.62 & 0.62 & 0.67 & 0.62 & 0.78 & 10.13 \\
\hline Pu-240 & 0.20 & 0.27 & 0.27 & 0.27 & 0.27 & 0.53 & 3.13 \\
\hline Pu-241f & 0.07 & 0.10 & 0.10 & 0.10 & 0.18 & 0.35 & 0.30 \\
\hline Pu-242 & 0.04 & 0.07 & 0.06 & 0.06 & 0.08 & 0.25 & 0.13 \\
\hline MinorAct & 0.10 & 0.17 & 0.17 & 0.16 & 0.12 & 0.16 & 0.33 \\
\hline
\end{tabular}


Appendix C - Cost Impact on Nuclear and Fossil Generating Technologies

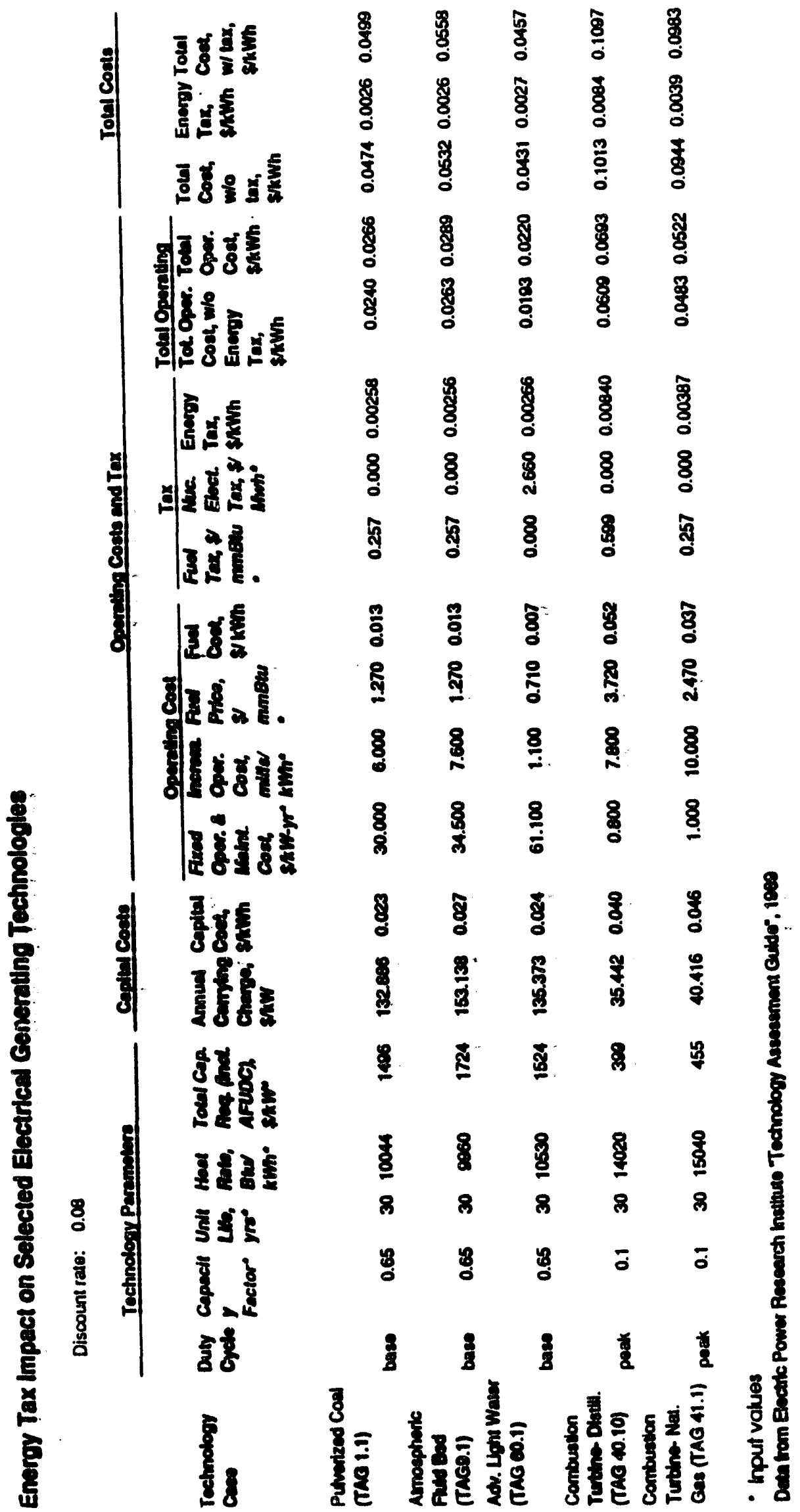




\section{Appendix D - Treasury Statement}




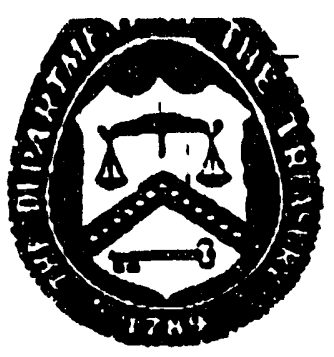

\section{DEPARTMENT OF: THE TREASURY OFFICE OF TAIX ANALYSIS \\ 1500 Pennsylvania. Avenue, N.W. \\ Washington, D.C. 20220}

Number of pages: $C+16$

DATE: $4-8-73$

TO: ALLEN LAMONT $5: 10 \cdot 422 \cdot 2654$

FAX numbor

Confimatien mumber

FROM: $\frac{\text { J.M NUNNS. }}{\text { Nam }}$ $1622-1328$ Prove number

Sender's FAX number: 202/622-0236 Location: Room 4112MT

Sender's Confirmation Number: 202r622-2659

Comments/Special Instructions:

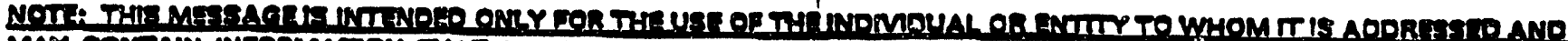

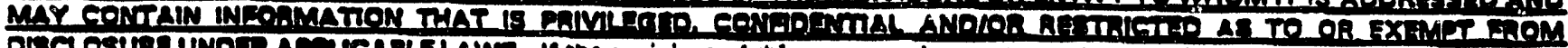

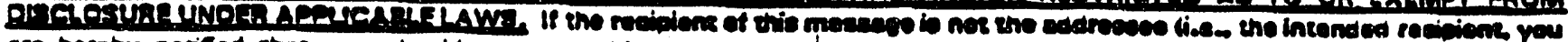

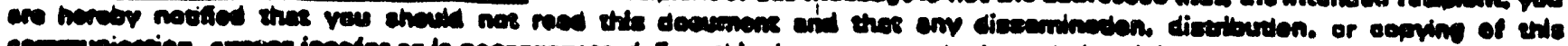

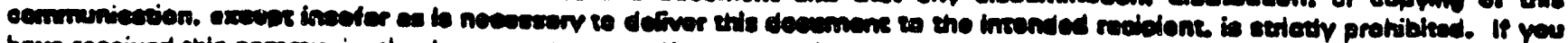

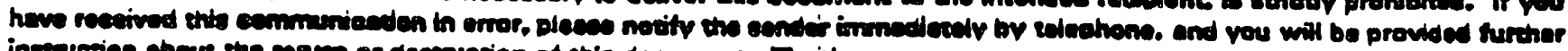

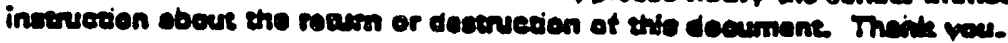




\section{DESCRIPHION OR MODHIDD BIU TAX}

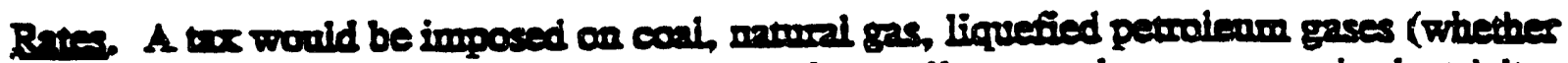

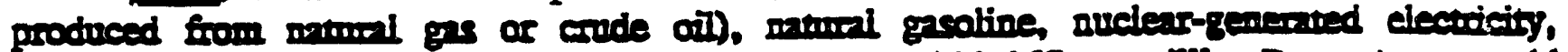
hydroelectriaity, and inparted elescriaity at a besic rate of 50.257 per million Btus. A tax would be imposed on refined petroienm produces (cther than liquefied petrolenm gases and naturi

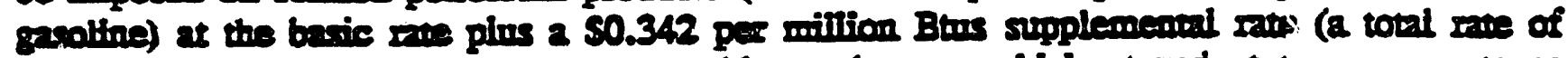

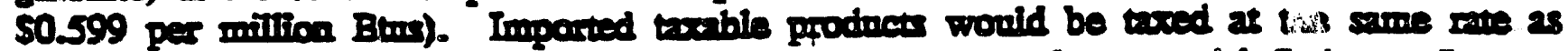

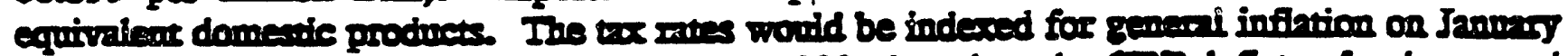
I af exch year beginning in 1998. Indeaing woald be based on the GDP deflator for the second

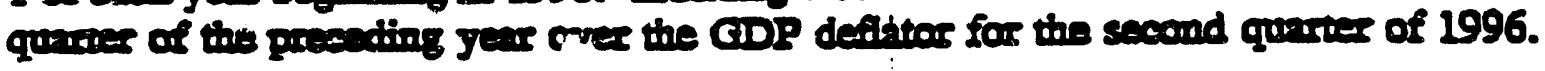

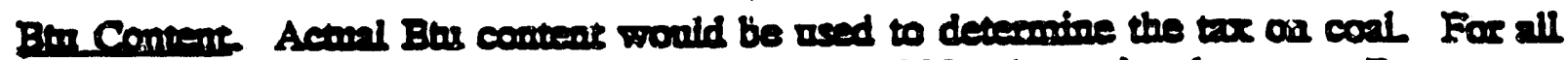

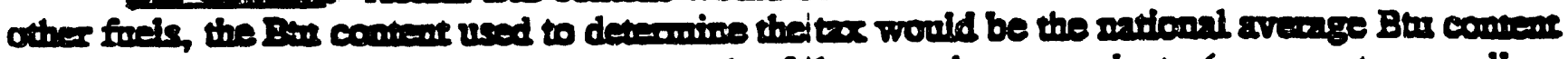

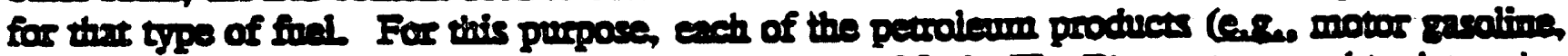
disillate frel oil) would be treated as a separate type of fuel. The Bto content used to determine

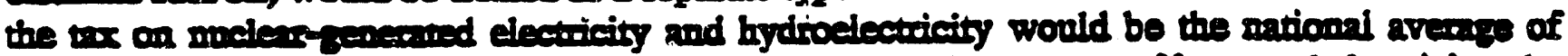

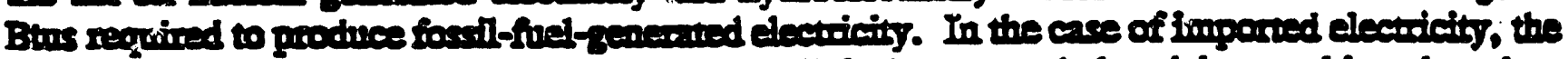

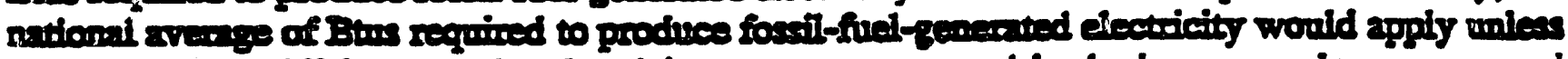

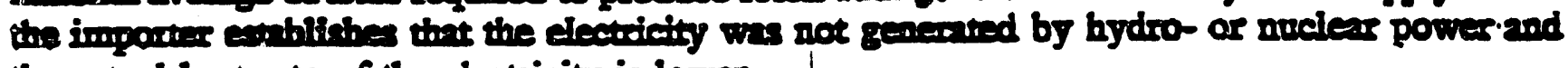
the exenl hent on of the electricity is lower.

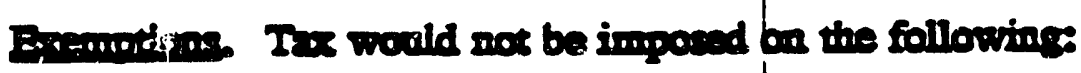

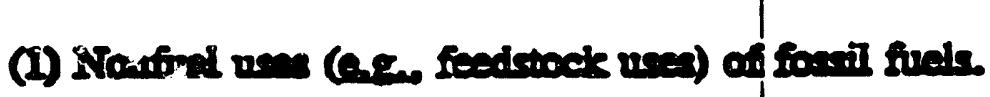

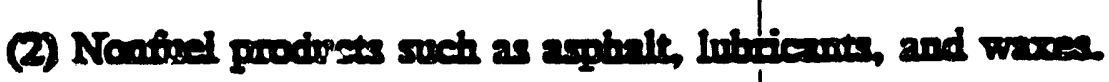

(3) Expoxad foels and electricity (m spreoprinte refund or credit would be provided for forcil-foll-goneconod Electricity).

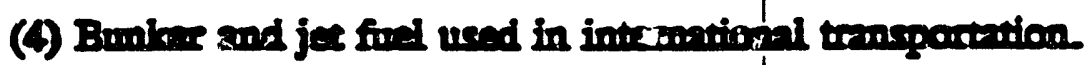

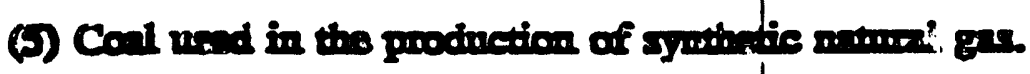

(6) Coll som mothone from opecoting mines.

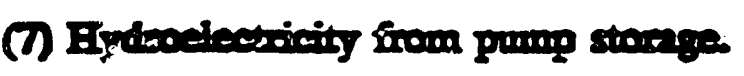

(8) Namal gas uved in enhanced oil recovery for hervy oil.

(9) Imparted electricity if the imparter esublishes that an energy source other than fosail Sols, hydropower, of nueienr power way used to generate the electricity.

(10) Ethonol, methanol, EIBE, MTBE, and feedrsocias used in their productisn. 
(11) Biomass includins handem gas, wood waste, and bagasee (sugar cane biomass).

(12) Mnmicipal solid waste and tires bured as fuel.

(13) Solar, wind, and geothermal energy!

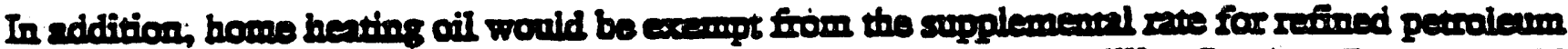
prodnets (hei. It would be troed at the basic rate of 50.257 per million Btor). The wa would not inelude exemption besed on the chrnecter af the purchaser of an otherwise trable product

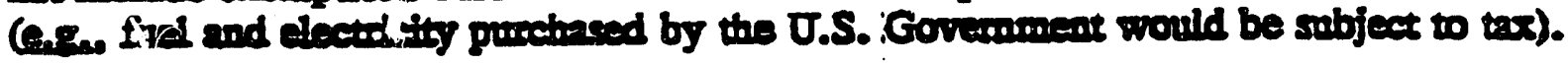

Collention. Point. The tex on refined petroleum products (including liquefied petroleam

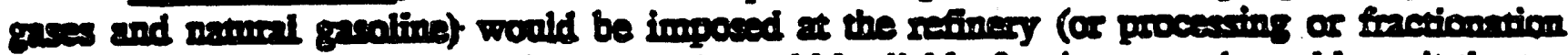

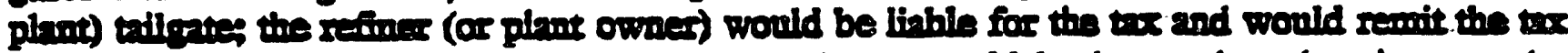

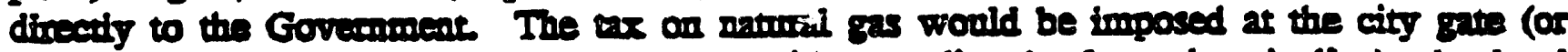
equivient in the case of cod users that receive gas directly from the pipeline); the locel distribution company (or end nesr receiving gas from the pipeline) would be liable for the thes, but the tax would be collested and seovitued to the Govecoment by tho pipeline. The was on cond would be imponed at the point of receipt by the end user, the end neme would be liable for the

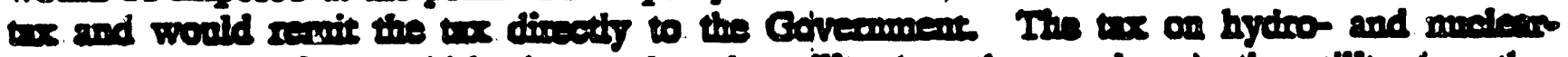

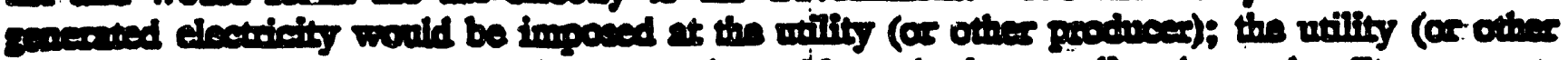

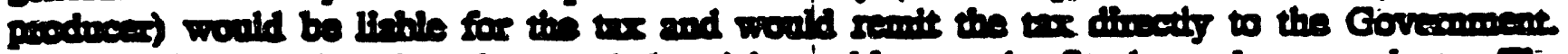

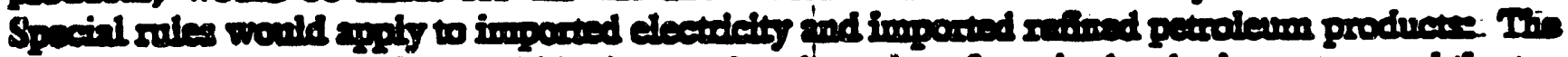

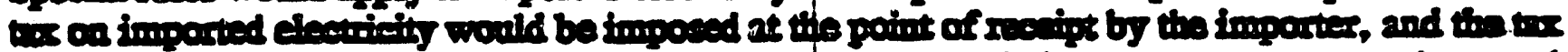

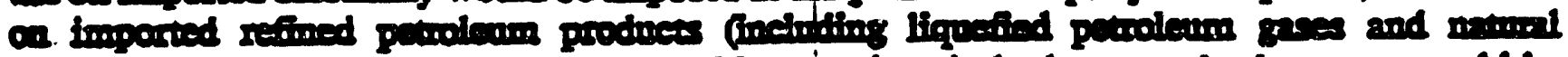

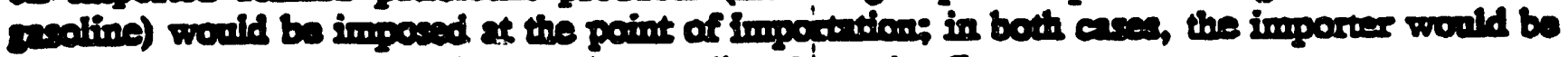

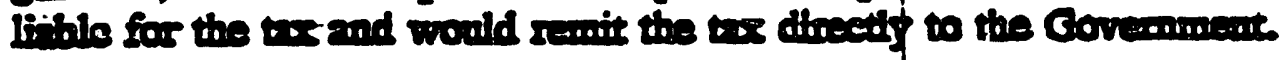

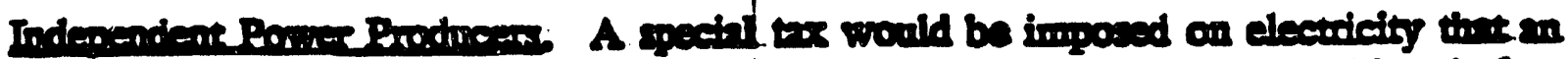

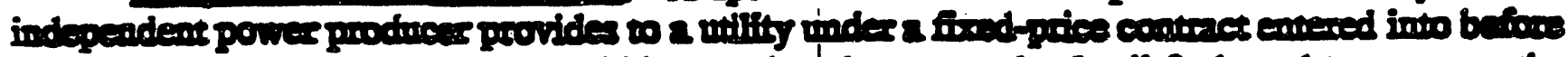

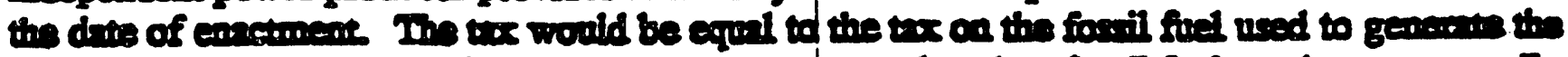

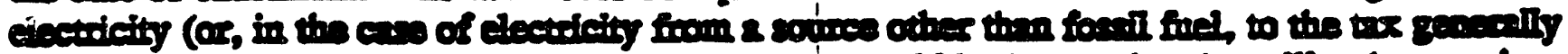

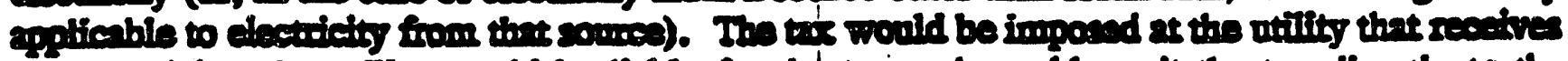
the electricity; the woilhy would be liable for the tax and wooild remit the tax directy to the Goveroment The indepeadent power producer wopld not be liable for any wo on the electricity

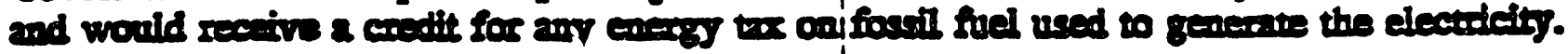

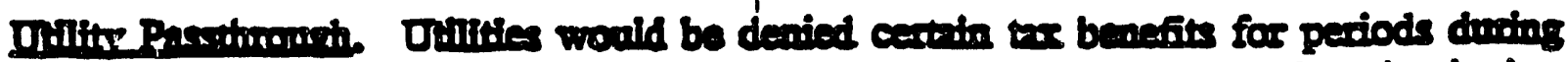
which the eners tox is noc completely passed twough to ead usece. The Administration invites commens on the implementrion of this proposell

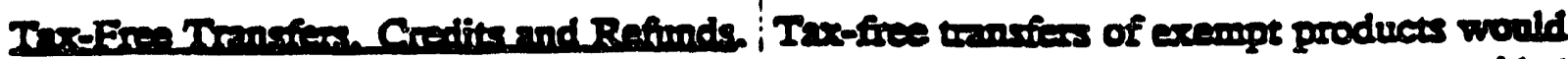

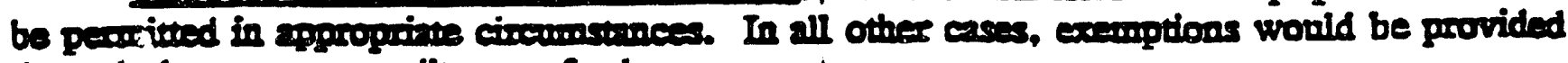
twough downstrener crodis or refinde. 
Ifse Tax. A use wx would be imposed on fuel uses of tromble produets on which the energy tor has not been imposed and on fuel uses of crude oil. This trox woxid apply to frel use of produes that hrve not reached the point at which tax is normally imposed, to nonecrempt use of products purebased under 2 cinim of exemption, and to nomresidential fuel ues of home heating oil. The use bre would not apply to errde oil or natural gas used, on the prewises where

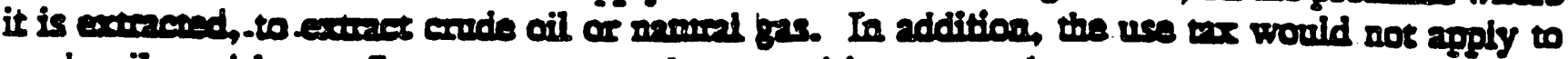
condr, oil used in a refinery or w naturi gas used in a namel gas procensing or frectionation

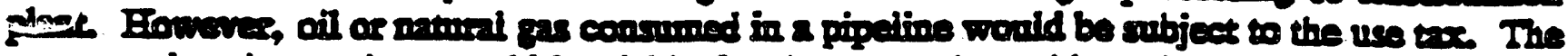

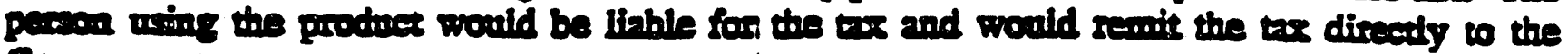
Goveromente.

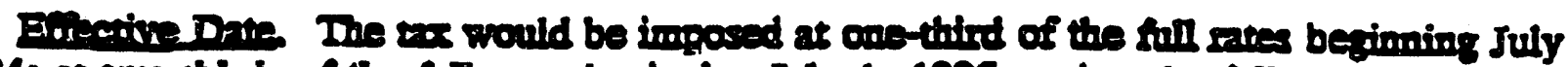
1, 1994; at 2wo-thieds of the full eaves becinning July 1, 1995; and at the toll rates beginning July 1, 1996.

Eionestroke Tre. Foor swocks troes would be imposed on July 1, 1994, and on the dare

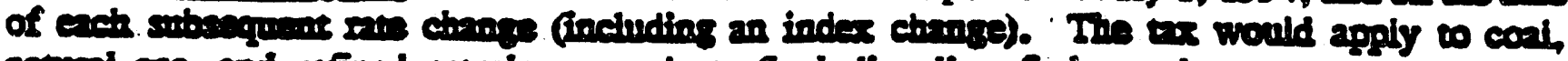

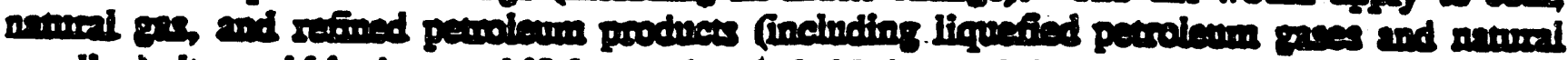

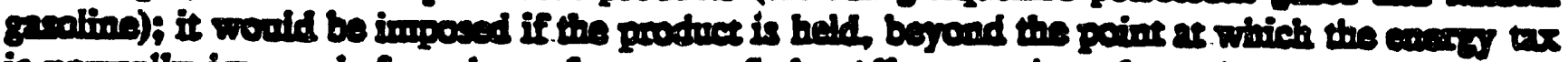

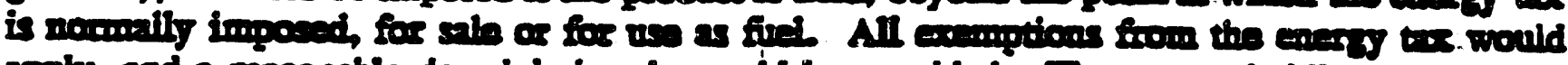
apply, and a sencomble de minimis role would be provided The peocon holding the worble

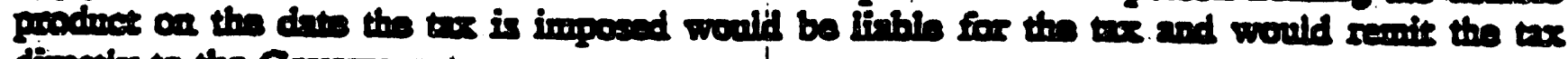
divecty to the Governomente 
1

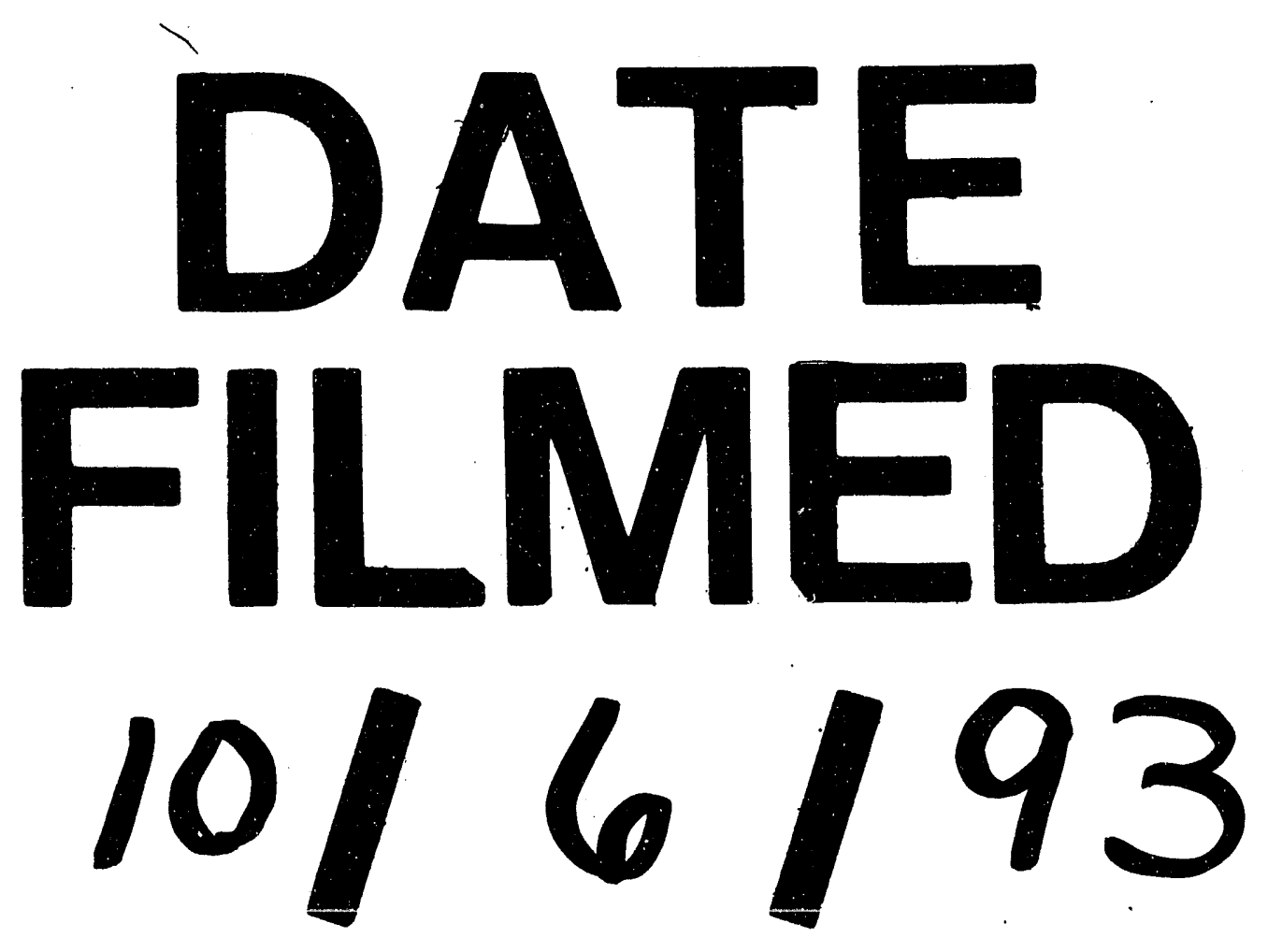


